\title{
Penerapan Association Rule Mining Berbasis Algoritma Frequent Pattern Growth Untuk Rekomendasi Penjualan
}

\author{
Didi Supriyadi*1, Ardelia Mahardika ${ }^{2}$ Atik Febriani $^{3}$ \\ ${ }^{1}$ Program Studi S1 Sistem Informasi, Institut Teknologi Telkom Purwokerto \\ ${ }^{2}$ Program Studi S1 Informatika, Institut Teknologi Telkom Purwokerto \\ ${ }^{3}$ Program Studi S1 Teknik Industri, Institut Teknologi Telkom Purwokerto \\ e-mail: 1didisupriyadi@ ittelkom-pwt.ac.id, ${ }^{2} 15102010 @$ ittelkom-pwt.ac.id, ${ }^{3}$ atik@ittelkom-pwt.ac.id
}

\begin{abstract}
Abstrak
Tingkat persaingan dan kompleksitas permasalahan penjualan pada perusahaan retail, menuntut setiap perusahaan retail untuk mampu berkompetisi dengan perusahaan lain. Salah satu yang dapat dilakukan adalah melalui pengambilan keputusan terkait penjualan yang lebih tepat dan efektif. Besarnya data transaksinonal penjualan perusahaan retail dapat dilakukan ekstraksi informasi yang bermanfaat. Metode yang dapat digunakan untuk menggali informasi adalah melalui penerapan association rule mining. Association Rule Mining merupakan suatu metode data mining yang berfokus pada pola transaksi dengan cara mengekstraksi asosiasi atau hubungan suatu kejadian. Keranjang belanja yang terdapat pada perusahaan retail yang terkomputerisasi merupakan cara terbaik untuk memberikan dukungan rekomendasi keputusan secara ilmiah dengan cara menentukan hubungan antara barang yang dibeli secara bersamaan dalam setiap transaksi. Algoritma FP-growth digunakan untuk menentukan himpunan dataset yang paling sering muncul (frequent itemset) pada sekeompok data. Penelitian ini menghasilkan nilai minimum support 0,1\% dan nilai minimum confidence $60 \%$ jumlah rule yang dihasilkan berjumlah 116457, nilai minimum confidence $70 \%$ jumlah rule yang dihasilkan berjumlah 84086, dan nilai minimum confidence $80 \%$ jumlah rule yang dihasilkan berjumlah 48623 dari data yang diolah sebanyak 22191. Hasil rule ini dapat digunakan untuk strategi pemasaran produk. Nilai minimum support 0,1\% dimana semakin besar nilai minimum confidence maka menghasilkan rule yang semakin sedikit.
\end{abstract}

Kata kunci-Data Mining, Association rule mining, FP-Growth

\section{Abstract}

The level of competition and complexity of sales problems at retail companies, requires each retail company to be able to compete with other companies. One thing that can be done is through making decisions regarding sales that are more appropriate and effective. The amount of transactional data on retail company sales can be extracted useful information. The method that can be used to gather information is through the application of association rule mining. Association Rule Mining is a data mining method that focuses on transaction patterns by extracting associations or relationships of events. The market basket in a computerized retail company is the best way to provide scientific decision support support by determining the relationship between items purchased simultaneously in each transaction. FP-growth algorithm is used to determine the set of datasets that most often appear (frequent itemset) in a group of data. This research resulted in a minimum support value of $0.1 \%$ and a minimum value of $60 \%$ confidence in the number of rules produced amounted to 116457, a minimum value of $70 \%$ confidence in the number of rules produced amounted to 84086, and a minimum value of $80 \%$ confidence in the number of rules generated amounted to 48623 from the data processed in a number 22191. The results of this rule can be used for product marketing strategies. The minimum value of support is $0.1 \%$ where the greater the minimum value of confidence will result in fewer rules.

Keywords - Data Mining, Association rule mining, FP-Growth 


\section{PENDAHULUAN}

$\mathrm{S}$ eiring dengan laju pertumbuhan industri retail dan perbelanjaan, tidak terlepas dari permasalahan. Salah satu permasalahan yang dihadapi oleh industri retail adalah terkait pengambilan keputusan penjualan yang tepat dan efektif untuk meningkatkan laba perusahaan sehiangga mampu berkompetisi dengan kompetitor lainnya. Pemodelan keterhubungan antar item produk dalam setiap transaksi penjualan yang terkomputerisasi dapat digunakan dalam pengambilan keputusan bagi perusahaan melalui penambangan data atau data mining.

Tujuan dari data mining adalah untuk dapat memahami data dalam jumlah yang besar akan tetapi kurang menjadi perhatian (unsupervised) pada beberapa domain [1]. Berdasarkan tujuan tersebut untuk dapat memahami data, memiliki arti yang berbeda - beda tergantung pada pengalaman dan kebutuhan pengguna. Untuk dapat dipahami sebagai pengetahuan yang baru, perlu memperhatikan serangkaian atribut - atribut penting pada sekelompok data. Pengetahuan baru tersebut harus dapat dipahami, valid, baru dan memiliki manfaat. Hal terpenting adalah pengetahuan baru tersebut harus mampu dipahami oleh pemilik data untuk digunakan dalam kepentingan - kepentingan lain serta untuk memberikan keuntungan. Algoritman data mining terbagi dalam dua katergori yaitu deskriptif dan prediktif. Deskriptif digunakan untuk mengukur kesamaan antar objek maupun menemukan pola hubungan yang belum diketahui dalam sekelompok data, sedangkan prediktif untuk penyimpulan rule prediksi dari data pelatihan yang selanjutnya rule tersebut digunakan pada data yang belum terprediksi [2].

Transaksi penjualan pada perusahaan retail jumlahnya mengalami peningkatan setiap waktunya. Hal ini didorong oleh semakin meningkatnya minat dan kebutuhan konsumen akan kebutuhan pokok maupun sekunder yang dijual oleh perusahaan retail. Besarnya data transaksinonal penjualan perusahaan retail tersebut dapat dilakukan ekstraksi informasi yang bermanfaat. Metode yang dapat digunakan untuk menggali informasi tersebut melalui penerapan association rule mining.

Association Rule Mining merupakan suatu metode data mining yang berfokus pada pola transaksi dengan cara mengekstraksi asosiasi atau hubungan suatu kejadian. Keranjang belanja yang terdapat pada beberapa perusahaan retail yang terkomputerisasi merupakan cara terbaik untuk memberikan dukungan rekomendasi keputusan secara ilmiah dengan cara menentukan hubungan antara barang yang dibeli secara bersamaan dalam setiap transaksi [3]. Melalui ekstraksi hubungan barang dalam setiap transaksional penjualan dapat membantu pihak pengambil keputusan pada perusahaan retail untuk menentukan strategi penjualan yang lebih tepat dan akurat. Pengambilan keputusannya dapat berupa penentuan pola rekomendasi maupun penawaran promo penjualan barang yang dipaketkan dengan produk lain yang saling berasosiasi [4]. Association rule mining merupakan salah satu metode data mining tidak terbimbing (unsupervised) yang digunakan untuk menemukan keterikatan asosiasi hubungan atau ketergantungan pada sebuah sekelompok data yang besar [1][5]. Association rule merupakan tools data mining untuk mengekstraksi pengetahuan dari sekumpulan data. Penemuan hubungan asosiasi dalam sebuah informasi sering digunakan dalam bisnis untuk membantu pengambilan keputusan. Salah satu penerapan association rule pada bisnis yaitu market basket data analysis.

Market basket analysis, merupakan salah satu penerapan dari association rule yang intuitif. Hal ini karena mampu menganalisis pola pembelian yang dilakukan oleh pelanggan memalui penemuan asosiasi antara barang atau produk yang dipilih pelanggan secara bersamaan dalam setiap transaksi pembelian. Sebagai contoh dapat diketahui misalkan jika pelanggan membeli roti biasanya akan bersama - sama membeli susu dan berbagai pola pasangan produk lainnya. Hal tersebut jika dapat diketahui oleh pihak penjual, maka dapat digunakan untuk

Didi, et,al (Penerapan Association Rule Mining Berbasis Algoritma Frequent Pattern Growth untuk Rekomendasi Penjualan) 
meningkatkan profit penjualan melalui kampanye marketing yang didesain sebaik mungkin maupun mendesain layout toka untuk memberikan pelayanan pelanggan yang lebih optimal.

Penentuan himpunan data yang paling sering muncul (frequent itemset) dalam sejumlah data dapat menggunakan algoritma Frequent Pattern Growth (FP-Growth). FP Growth merupakan pengembangan dari algoritma Apriori. Kelebihannya adalah tidak dilakukan pemindahan data transaksi secara berulang - ulang. Proses pemindahan data yang berulang ulang dapat menyebabkan proses komputasi yang lebih lama. Hal ini dikatakan algoritma FP Growth dinilai sebagai algoritma baru yang lebih efektif. Pada algoritma FP Growth, informasi mengenai frequent itemset dalam bentuk struktur prefix-tree atau sering disebut $F P$-Tree [6].

Berdasarkan permasalahan yang telah dipaparkan sebelumnya, maka perlu diujikan Algoritma FP-Growth yang diterapkan pada Association rule mining. Algoritma FP-Growth dalam penelitian ini digunakan untuk menentukan asosiasi antar produk pada data lampau transaksional perusahaan retail. Hal ini dimaksudkan untuk menemukan pola keterhubungan antar item/ produk pada transaksional penjualan.

\section{METODE PENELITIAN}

Tahapan penelitian yang dilalui dalam penelitian ini dilakukan secara iterative seperti ditunjukkan Gambar 1 sebagai berikut:

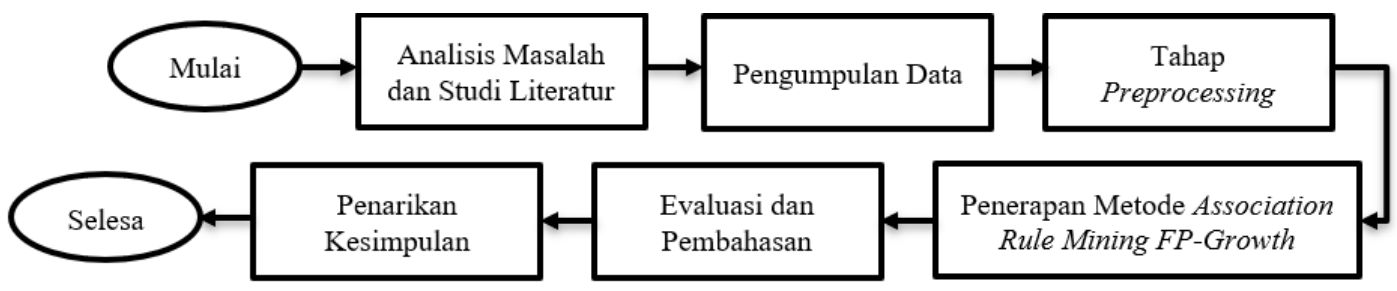

Gambar 1. Tahapan Penelitian

\subsection{Tahap Analisis Masalah dan Studi Literatur}

Tahapan ini dilakukan untuk mengidentifikasi permasalahan yang ada serta mempelajari studi literatur yang relevan dengan permasalahan untuk menentukan ruang lingkup, metode penyelesaian masalah yang tepat. Bererapa studi literatur yang digunakan pada penelitian ini antara lain:

\subsubsection{Data Mining}

Data mining juga merujuk sebagai proses penemuan pengetahuan (knowledge discovery process) baru dari basis data [7]. Hal ini menunjukkan bahwa data mining merupakan proses ekstraksi data secara implisit yang penting, untuk menggali informasi yang tidak diketahui sebelumnya dan berpotensi memberikan manfaat dari data dalam database. Gambar 2 menunjukkan salah satu model Knowledge Discovery Process (KDP) data mining yaitu Cross Industry Standard Process Data Mining (CRISP-DM) KDP. 


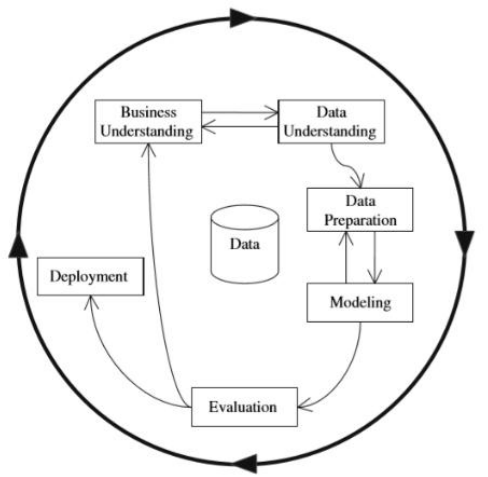

Gambar 2. CRISP DM Knowledge Discovery Process Model [1]

CRISP DM KDP model memiliki 6 (enam) tahap sebagai berikut:

1. Business understanding. Tahap ini fokus untuk memahami tujuan dan kebutuhan dari perspektif bisnis. Adapun langkah - langkah turunan tahap ini meliputi: mendeterminasikan tujuan dari bisnis, menganalisis situasi, mendeterminasikan target dari data mining, dan Menyusun rencana proyek.

2. Data understanding. Langkah ini diawali dengan pengumpulan dan proses pengenalan data. Langkah - Langkah turunan dari tahap ini meliputi: pengumpulan data inisial, mendeskripsikan data, mengeskplorasi data, dan memverifikasi kualitas data.

3. Data preparation. Tahap ini meliputi semua aktivitas yang dibutuhkan untuk membangun dataset akhir dimana data tersebut akan digunakan atau dimasukkan sebagai tool data mining tahap selanjutnya. Tahapannya meliputi: pemilihan data, pembersihan data, mengkonstruksi data, mengintegrasikan data dan memformat data sebagai substeps.

4. Modeling. Pada tahap ini Teknik pemodelan di pilih dan diterapkan. Tahapannya sebagai berikut: memilih Teknik atau model, menciptakan desain pengujian, menciptakan/membuat model, dan menguji model yang telah di generate.

5. Evaluation. Selanjutnya setelah model dikembangkan, model tersebut harsu dievaluasi dari perspektif tujuan bisnis. Pada tahap ini, keputusan penggunaan hasil Data mining harus dicapai. Adapun substeps dari tahap ini meliputi: evaluasi hasil, mereview proses, dan mendeterminasikan langkah selanjutnya.

6. Deployment. Tahap selanjutnya dalam knowledge discovery process adalah deployment. Setelah pengetahuan diperoleh, maka harus diorganisir dan disajikan sedemikian rupa hingga dapat digunakan oleh user. Tahap deployment bergantung pada kebutuhan. Hal ini dapat dilakukan dengan sesederhana mungkin atau kompleks dalam menerapkan proses penemuan pengetahuan yang berulang. Substeps dari tahap ini meliputi: rencana deployment, rencana monitoring dan pemeliharaan.

\subsubsection{Association Rule Mining}

Penentuan akan adanya hubungan relasi antar beberapa variasi produk ataupun pola kemunculan dapat menggunakan association rule mining. Pada association rule mining, dikatehui secara umum batasan nilai minimal pada dua parameter yaitu support dan confidence yang menunjukkan aturan hubungan dalam dataset. Support merupakan bagaimana frekuensi kemunculan barang atau produk dalam transaksi di dalam database penjualan yang dinotasikan dengan simbol W. Sedangkan confidence menunjukkan jumlah transaksi yang dinotasikan dengan simbol T [8][9]. Hubungan kedua parameter ditunjukkan dalam rumus berikut:

Support $(W)=$ frekuensi kemunculan produk $(W) /$ total jumlah transaksi $(T)$

Didi, et,al (Penerapan Association Rule Mining Berbasis Algoritma Frequent Pattern Growth untuk Rekomendasi Penjualan) 
Dan untuk support untuk dua produk yang direpresentasikan dengan produk $\mathrm{V}$ dan $\mathrm{W}$ maka dirumuskan sebagai berikut:

Support $(V W)=$ frekuensi kemunculan produk $V$ dan $W$ secara bersamaan/ total jumlah transaksi (T)

Parameter confidence digunakan untuk menunjukkan seberapa kuat hubungan kebenaran yang sering muncul dalam database transaksi. Hal ini dinotasikan dengan simbol $\mathrm{V} \Rightarrow \mathrm{W}$ dan dirumuskan sebagai berikut:

$$
\text { Confidence }(V=>W)=\operatorname{support}(V W) / \operatorname{support}(V)
$$

\subsubsection{FP Growth}

Algoritma FP Growth telah diinisialisasi dan diajukan oleh Han. Menurut Han, FP growth merupakan metode yang efisien dan scalable untuk menggali frekuensi pola dari sekelompok set yang lengkap dengan proses pola pertumbuhan fragmen atau pecahan [10]. Algoritma FP-Growth pengembangan dari algoritma Apriori ini terletak dalam scanning database dan akurasi rules. FP-Growth lebih memberikan keuntungan karena hanya dilakukan satu atau dua kali saja scanning database sedangkan pada Apriori dilakukan scanning database secara berulang-ulang. Pada Apriori akurasi rules-nya lebih tinggi daripada FP-Growth. Namun, karena scanning dilakukan secara berulang-ulang kecepatannya akan menjadi lebih lambat. Walau demikian, kedua algoritma ini memiliki tujuan yang sama yaitu menentukan frequent itemset [11].

Tahapan yang dilalui dalam menentukan frequent itemset, dimana dari data set yang pertama kali dilakukan adalah penentuan minimum support. Selanjutnya menentukan header frequent itemset dan membuat FP-Tree. Pada FP-Tree yang ada, digunakan untuk membuat Conditional Pattern yang selanjutnya dilakukan frequent itemset. Gambar 3 menunjukkan Blok Diagram Algoritma FP-Growth.

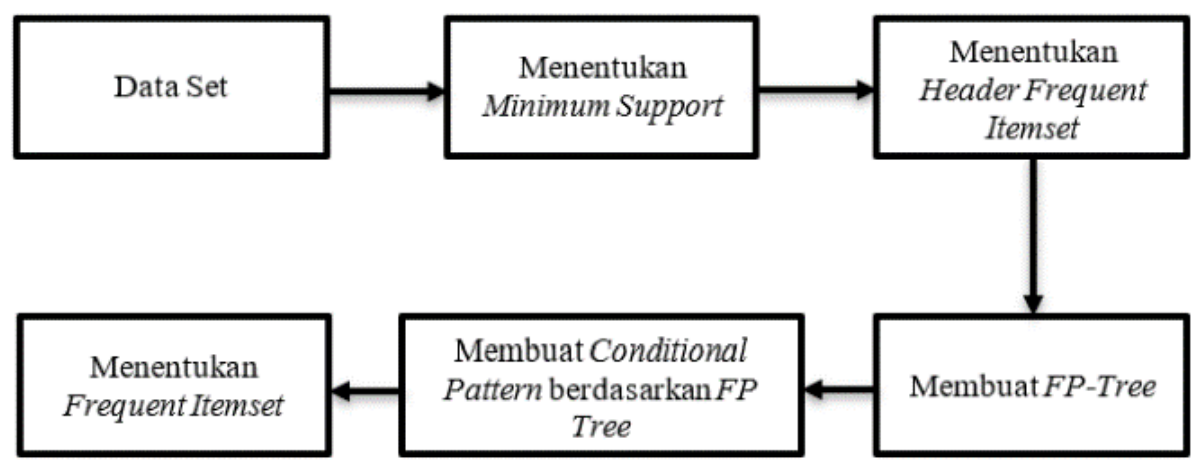

Gambar 3. Blok Diagram Algoritma FP-Growth

Pembangunan FP-Tree dilakukan dengan memetakan setiap data ke dalam lintasan tertentu pada $F P$-Tree. Setiap transaksi yang dipetakan memungkinkan terdapat transaksi yang memiliki item yang sama. Semakin banyak data transaksi yang memiliki item yang sama, maka proses pemampatan dengan struktur data FP-Tree menjadi lebih efektif [4].

\section{Pengumpulan Data}

Data yang dikumpulkan merupakan dataset online retail dari website UCI Machine Learning Repository dengan subyek Online Retail Dataset. Online Retail Dataset merupakan data transaksional memuat 541.909 jumlah baris data dari tahun $2010-2011$.

Didi, et,al (Penerapan Association Rule Mining Berbasis Algoritma Frequent Pattern Growth untuk Rekomendasi Penjualan) 


\section{Tahap Preprocessing}

Tahap preporcessing dilakukan untuk menyeleksi dan memvalidasi dataset dari data yang kualitasnya kurang baik misalkan bersifat noisy, redudansi, data tidak konsisten, maupun data yang tidak sesuai rule tertentu. Tahap preprocessing ini meliputi data cleaning yang dilakukan melalui penghapusan inkonsistensi data, data reduction untuk menghapus atribut - atribut data yang tidak digunakan, dan selanjutnya adalah transformed data untuk melakukan proses pengolahan data ke dalam bentuk biner.

\section{Penerapan Metode Algoritma Association Rule Mining FP-Growth}

Tahap ini proses data mining dilakukan menggunakan metode Association Rule Mining dan menerapkan algoritma FP-Growth. Algoritma FP-growth ini digunakan untuk menentukan himpunan dataset yang paling sering muncul (frequent itemset) pada sekeompok data. Tahap ini dilakukan menggunakan software RStudio yang menerapkan Bahasa pemrograman R. Pada tahap penerapan Association Rule Mining dilakukan dengan mencari frequent itemset dengan mencari nilai support dan nilai confidence.

\section{Tahap Evaluasi dan Pembahasan}

Tahap ini dilakukan untuk mengevaluasi tingkat validitas rule menggunakan Lift Ratio setelah diketahui nilai support dan nilai confidence suatu data.

\section{Tahap Penarikan Kesimpulan}

Setelah diketahui validitas dari suatu rule menggunakan Lift Ratio, maka dapat dilakukan penarikan kesimpulan untuk pertimbangan pengambilan keputusan.

\section{HASIL DAN PEMBAHASAN}

\subsection{Pengumpulan Data}

Pengumpulan data dilakukan dengan menggunakan data set Online Retail dari website UCI Machine Learning Repository dengan nama subjek Online Retail Dataset. Online Retail data set merupakan data tranksaksional yang mengandung 541.909 jumlah baris data dan periode semua transaksi yang terjadi diantara tanggal 1 Desember 2010 sampai 9 Desember 2011. Seluruh atribut data set meliputi VoiceNo, Stock Code, Description, Quantity, Invoice Date, Unit Price, Customer ID dan Country.

\subsection{Preprocessing}

Tahap preprocessing dilakukan untuk menyeleksi dan memvalidasi data set dari data yang kualitasnya kurang baik bersifat noisy, redudansi, data yang tidak konsisten dan tidak sesuai dengan rule tertentu. Data set yang digunakan memiliki delapan buah indikator (atribut) dan 541.909 baris data. Sebelum melakukan data mining terdapat beberapa tahapan dalam melakukan preprocessing. Pertama, melakukan proses data cleaning dilakukan dengan menghapus inkonsistensi data pada atribut VoiceNo. Inkosistensi data yang dihilangkan pada VoiceNo memiliki kode 'c' yang artinya cancellation (pembatalan transaksi). Kedua, melakukan proses data reduction. Data reduction dilakukan untuk menghapus atribut yang tidak digunakan. Data set atribut yang digunakan hanya Description. Sementara pada atribut Voice No, Stock Code, Quantity, Invoice Date, Unit Price, Custome rID dan Country dihapus. Ketiga, melakukan transformed data. Proses transformed data merupakan data yang dipilih untuk 
melakukan proses pengolahan data. Setelah data set melalui proses preprocessing pada data set sekarang hanya mempunyai atribut Description dan 22191 transaksi.

\subsection{Pembentukan Frequent Pattern Tree (FP-Tree)}

$F P$ - Tree merupakan struktur penyimpanan data yang dibangun dengan memetakan setiap data transaksi ke dalam tiap lintasan tertentu. Setiap transksi yang dipetakan melalui $F P$ - tree memungkinkan adanya item yang sama, sehingga lintasannya akan saling menimpa. Semakin banyak data transaksi yang memiliki item yang sama, maka proses pemampatan dengan struktur FP-tree semakin efektif.

Selanjutnya, menentukan frekuensi pada setiap item dari keseluruhan transaksi yang telah dibatasi support count ke dalam sebuah tree. Misalnya telah ditentukan minimum support $0,1 \%$. Selanjutnya data yang memenuhi minimum support diurutkan berdasarkan pada frekuensinya dengan menambahkan Transaksi ID (TID) ke dalam dataset. TID berguna untuk memberikan nomor urut pada transaksi yang didasarkan pada frekuensi yang paling tinggi sampai paling rendah (Tabel 1).

Tabel 1. Frequent Pattern List

\begin{tabular}{|c|l|}
\hline TID & \multicolumn{1}{|c|}{ Item } \\
\hline 1 & $85123 \mathrm{~A}, 71053,84406 \mathrm{~B}, 84029 \mathrm{G}, 84029 \mathrm{E}, 22752,21730$ \\
\hline 2 & 22633,22632 \\
\hline 3 & $\begin{array}{l}84879,22745,22748,22749,22310,84969,22623,22622,21754,21755,21777, \\
48187\end{array}$ \\
\hline 4 & $22960,22913,22912,22914$ \\
\hline 5 & 21756 \\
\hline 6 & $\begin{array}{l}22728,22727,22726,21724,21883,10002,21791,21035,22326,22629,22659, \\
22631,22661,21731,22900,21913,22540,22544,22492, \text { post }\end{array}$ \\
\hline 7 & 22086 \\
\hline 8 & 22632,22633 \\
\hline 9 & $\begin{array}{l}851123 \mathrm{~A}, 71053,84406 \mathrm{~B}, 20679,37370,21871,21071,21068,82483,82486,82482, \\
82494 \mathrm{~L}, 84029 \mathrm{G}, 84029 \mathrm{E}, 22752,21730\end{array}$ \\
\hline 10 & 21258 \\
\hline 11 & $\begin{array}{l}85123 \mathrm{~A}, 71053,84406 \mathrm{~B}, 20679,37370,21871,21071,21068,82483,82486,82482, \\
82494 \mathrm{~L}, 84029 \mathrm{G}, 84029 \mathrm{E}, 22752,21730\end{array}$ \\
\hline
\end{tabular}

Langkah berikutnya adalah membangun pohon FP-Tree dengan melihat data sebelumnya. Pada TID 1 terdapat nilai $\{84406 \mathrm{~B}, 85123 \mathrm{~A}, 71053,84029 \mathrm{G}, 84029 \mathrm{E}, 21730,22752\}$ yang kemudian membentuk lintasan null $\rightarrow 84406 \mathrm{~B} \rightarrow 85123 \mathrm{~A} \rightarrow 71053 \rightarrow 84029 \mathrm{G} \rightarrow 84029 \mathrm{E} \rightarrow$ $21730 \rightarrow 22752$ dengan nilai support count awal bernilai satu seperti ditunjukkan gambar 4. Setelah pembacaan TID 1, maka selanjutnya membaca TID 2 yaitu \{22633, 22632\} dengan nilai support count tetap 1(Gambar 4) dikarenakan tidak ada transaksi dengan kode barang yang sama dengan pembacaan TID pertama. Hal ini dilakukan hingga TID terakhir yaitu TID 11 yang hasilnya terbentuk FP-Tree hingga pembacaan TID 11 seperti ditunjukkan gambar 5. 


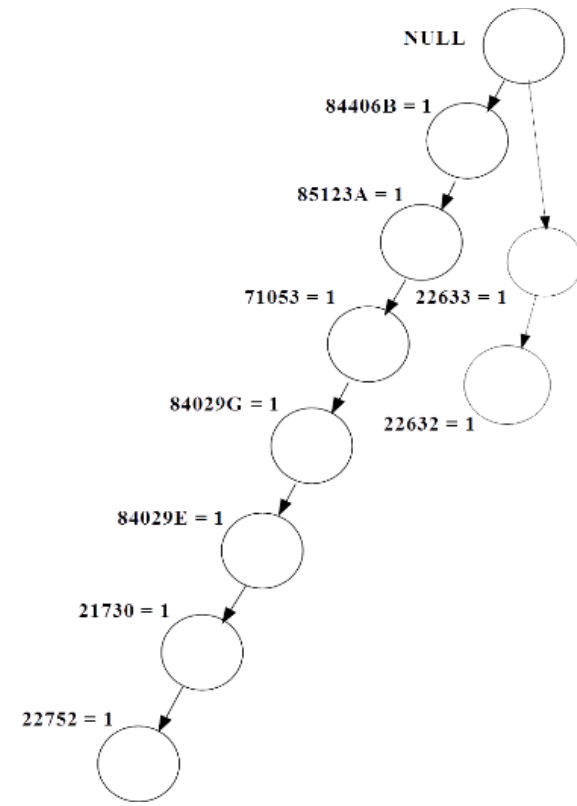

Gambar 4. Hasil Pembentukan FP-Tree Setelah Pembacaan TID 1 dan TID-2

Setelah melakukan pembentukan FP-Tree pembacaan TID 11 yang dijumlahkan berisi Null adalah - SET 7 BABUSHKA NESTING BOXES (22752) $=3$ - GLASS STAR FROSTED T-LIGHT HOLDER (21730) $=3-$ RED WOOLLY HOTTIE WHITE HEART $(84029 \mathrm{E})=3-$ CREAM CUPID HEARTS COAT HANGER $(84406 \mathrm{~B})=3-$ WHITE HANGING HEART TLIGHT HOLDER $(85123 \mathrm{~A})=3-$ WHITE METAL LANTERN $(71053)=3-$ HAND WARMER UNION JACK $(22633)=2-$ HAND WARMER RED POLKA DOT $(22632)=2$. Dan lintasan yang berakhir dengan support count terkecil yaitu 22632, 22633, 71053, 85123A, 840029E, 21730, dan 22752.

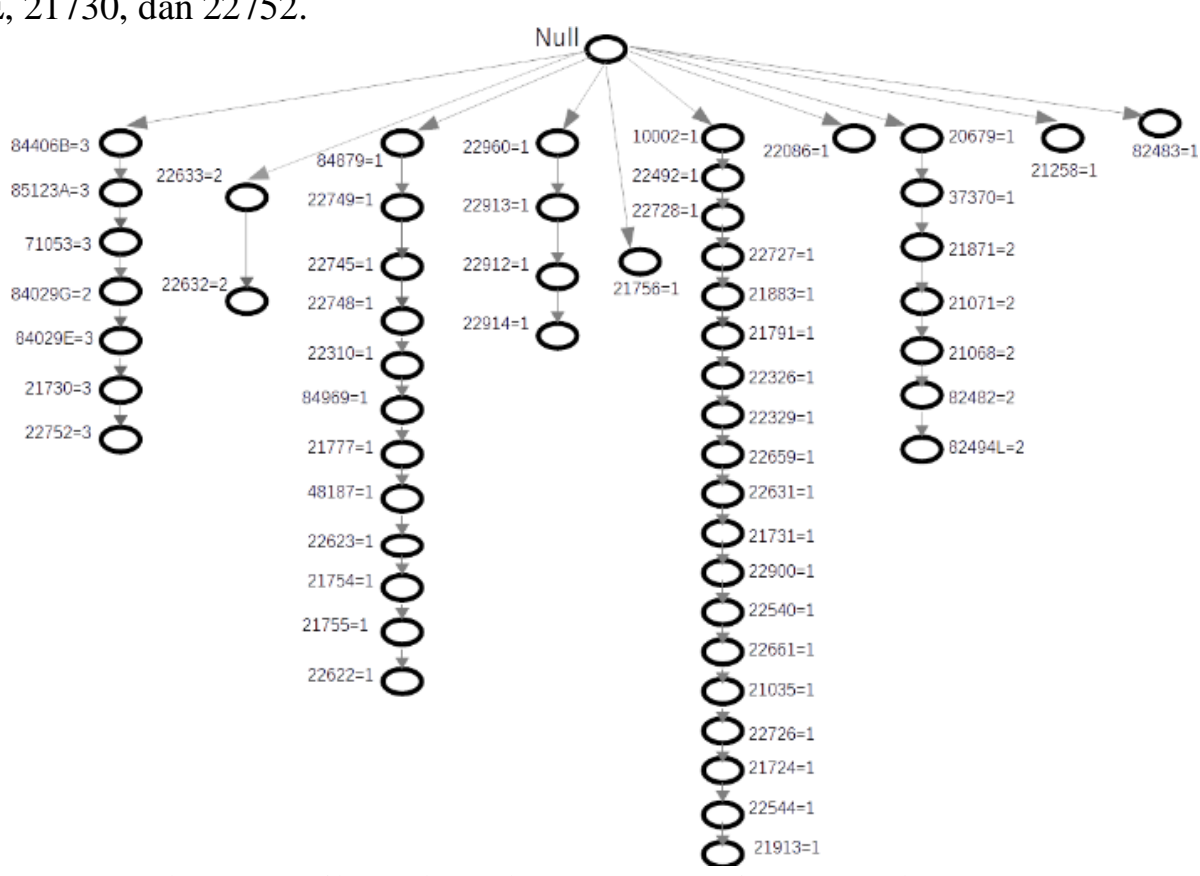

Gambar 5. Hasil Pembentukan FP-Tree Hingga Pembacaan TID11 


\subsection{Perhitungan pada Algoritma FP-Growth}

FP-Growth sama halnya dengan Apriori yang menerpakan perhitungan support, confidence dan lift ratio pada setiap rule. Pada FP-Growth melakukan scan pada data set yang berguna untuk mengetahui jumlah kemunculan satu item dalam semua transaksi yang berada dalam data set. Contoh rule yang digunakan adalah rule pertama pada gambar 6 berikut:

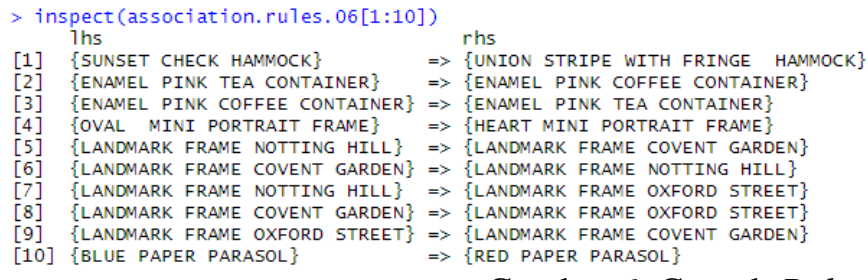

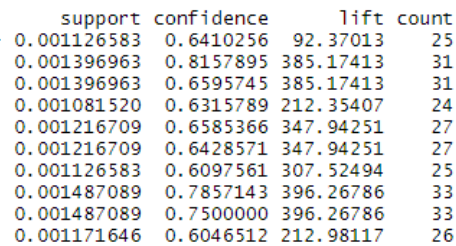

Gambar 6. Contoh Rule

Contoh rule yang diberikan adalah rule dengan satu itemset pada bagian Left Hand Side dan Right Hand Side. Dalam menghitung support maka perlu diketahui kemunculan jumlah item A dan B pada semua transaksi. Pada jumlah kemunculan item dengan description item Sunset Check Hammock dan Union Stripe With Fringe Hammock secara bersamaan dalam satu transaksi adalah sebanyak 26 kali dengan jumlah keseluruhan transaksi adalah 22191. Maka perhitungan untuk mencari nilai support berdasarkan rule adalah:

$$
\operatorname{Support}(A, B)=\frac{\sum \text { transaksi mengandung A dan } B}{\text { total transaksi }}=\frac{26}{22191}=0,001171646
$$

Selanjutnya, untuk mencari nilai confidence maka perlu diketahui jumlah kemunculan Left Hand Side dan Right Hand Side bersamaan dalam satu transaksi dan dengan jumlah kemunculan Left Hand Side dari semua transaksi. Pada kemunculan item Sunset Check Hammock dan Union Stripe With Fringe secara bersamaan adalah 26 kali sedangkan pada kemunculan item Sunset Check Hammock adalah sebanyak 40 kali. Maka, untuk mencari perhitungan nilai confidence berdasarkan rule adalah:

$$
\text { Confidence }(A, B)=\frac{\sum \text { transaksi mengandung } A \text { dan } B}{\text { total transaksi mengandung } \mathrm{A}}=\frac{26}{40}=0,65
$$

Hal pertama untuk mencari nilai lift ratio ialah nilai expected confidence harus ditentukan. Maka, perhitungan untuk mencari nilai expected confidence sebagai berikut:

$$
\text { Expected Conf }=\frac{\sum \text { transaksi mengandung B }}{\text { total transaksi }}=\frac{169}{22191}=0,0076157
$$

Kemudian, adapun perintah untuk menghitung nilai lift ratio dapat ditentukan dengan perhitugan:

$$
\text { Lift Ratio }=\frac{\text { Confidence }}{\text { Expected Confidence }}=\frac{0,65}{0,0076157}=85,35
$$

\subsection{Association Rule Mining FP-Growth}

Hasil proses association rule mining pada FP-Growth memiliki beberapa parameter, yaitu left hand side, right hand side, minimum support, minimum confidence dan minimum lift ratio. Parameter masukkan dengan minimum support 0,001 dan minimum lift ratio lebih dari satu. Hasil dari proses ini dapat ditunjukkan pada gambar 7 dibawah ini. 


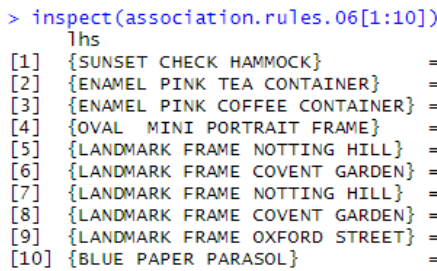

rhs

$\Rightarrow$ \{UNION STRIPE WITH FRINGE HAMMOCK

\{ENAMEL PINK COFFEE CONTAINER

\{ENAMEL PINK TEA CONTAINER

$\Rightarrow$ \{HEART MINI PORTRAIT FRAME\}

$\Rightarrow$ \{LANDMARK FRAME COVENT GARDEN\}

$\Rightarrow$ \{LANDMARK FRAME NOTTING HILL\}

$\Rightarrow$ \{LANDMARK FRAME OXFORD STREET

$\Rightarrow$ \{LANDMARK FRAME OXFORD STREET

$\Rightarrow\{$ LANDMARK FRAME COVENT
$\Rightarrow\{$ RED PAPER PARASOL

Gambar 7. Rule FP-Growth dengan Confidence 60\%

$\begin{array}{rrrr}\text { support } & \text { confidence } & \text { lift } & \text { count } \\ 0.001126583 & 0.6410256 & 92.37013 & 25 \\ 0.001396963 & 0.8157895 & 385.17413 & 31 \\ 0.001396963 & 0.6595745 & 385.17413 & 31 \\ 0.001081520 & 0.6315789 & 212.35407 & 24 \\ 0.001216709 & 0.6585366 & 347.94251 & 27 \\ 0.001216709 & 0.6428571 & 347.94251 & 27 \\ 0.001126583 & 0.6097561 & 307.52494 & 25 \\ 0.001487089 & 0.7857143 & 396.26786 & 33 \\ 0.001487089 & 0.7500000 & 396.26786 & 33 \\ 0.001171646 & 0.6046512 & 212.98117 & 26\end{array}$

Hasil dari FP-Growth dengan nilai minimum confidence $60 \%$ memiliki jumlah rule yang dihasilkan berjumlah 116457 dan total transaksi yang dihasilkan 22191 dengan jumlah item yang dihasilkan berjumlah 7836. Sedangkan untuk proses association rule mining pada $F P$ Growth dengan nilai confidence $70 \%$ dapat ditunjukkan pada gambar 8 dibawah ini.

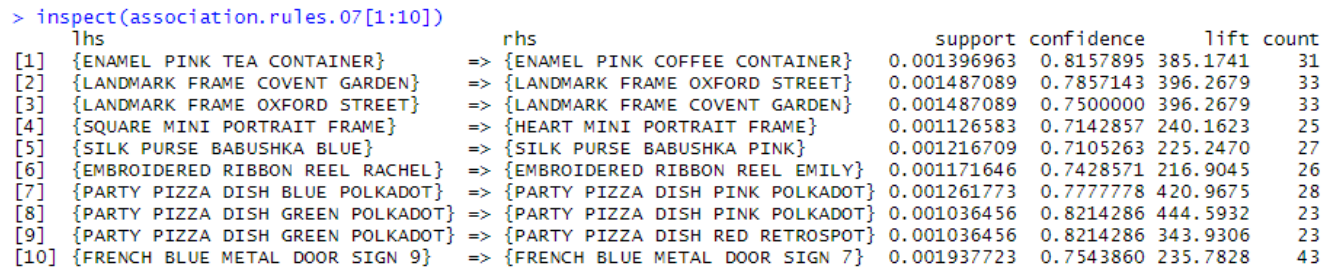

Gambar 8. Rule FP-Growth dengan Confidence $70 \%$

Hasil dari FP-Growth dengan nilai minimum confidence $70 \%$ memiliki jumlah rule yang dihasilkan berjumlah 84086 dan total transaksi yang dihasilkan 22191 dengan jumlah item yang dihasilkan berjumlah 7836. Sedangkan untuk proses association rule mining pada FP-Growth dengan nilai confidence $80 \%$ ditunjukkan pada gambar 9 dibawah ini.

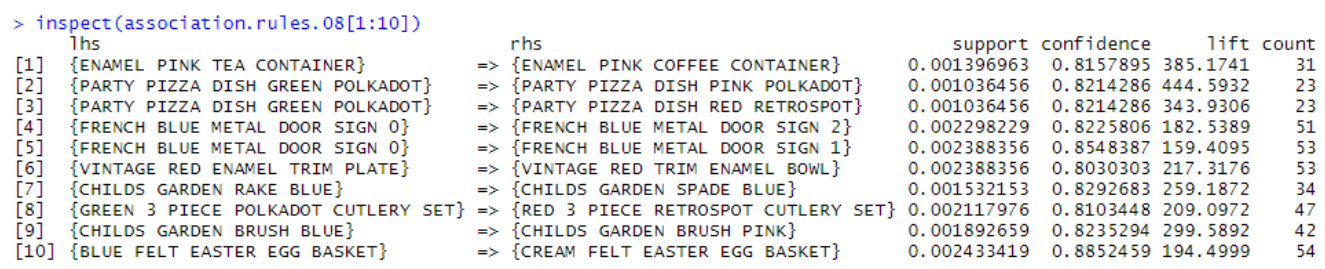

Gambar 9. Rule FP-Growth dengan Confidence $80 \%$

Hasil dari FP-Growth dengan nilai minimum confidence $80 \%$ memiliki jumlah rule yang dihasilkan berjumlah 48623 dan total transaksi yang dihasilkan 22191 jumlah item yang dihasilkan berjumlah 7836 . 


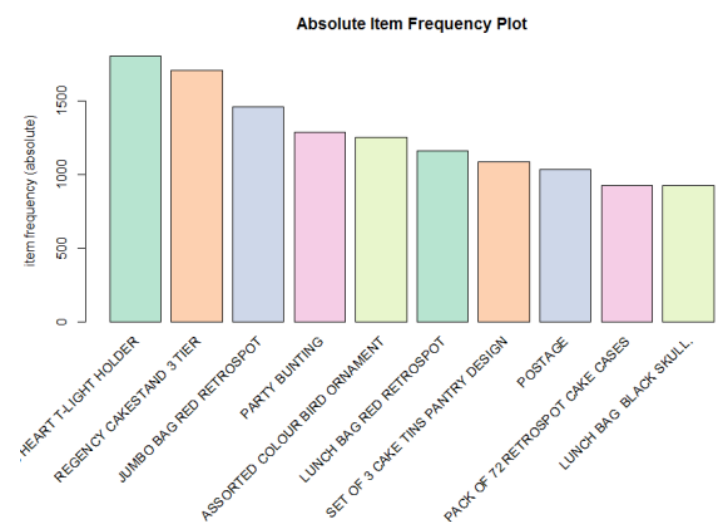

Gambar 10. Frekuensi 10 Item yang Sering Muncul

Pada gambar 10 item White Hanging Heart T-Light Holder merupakan item dengan urutan pertama yang paling banyak terjual dengan jumlah 1803. Item Regency Cakesand 3 Tier merupakan item dengan urutan kedua yang paling banyak terjual dengan jumlah 1709. Item Jumbo Bag Red Retrospot merupakan item dengan urutan ketiga yang paling banyak terjual dengan jumlah 1460. Item Party Bunting merupakan item dengan urutan keempat yang paling banyak terjual dengan jumlah 1285. Item Assorted Colour Bird Retrospot merupakan item dengan urutan kelima yang paling banyak terjual dengan jumlah 1250 .

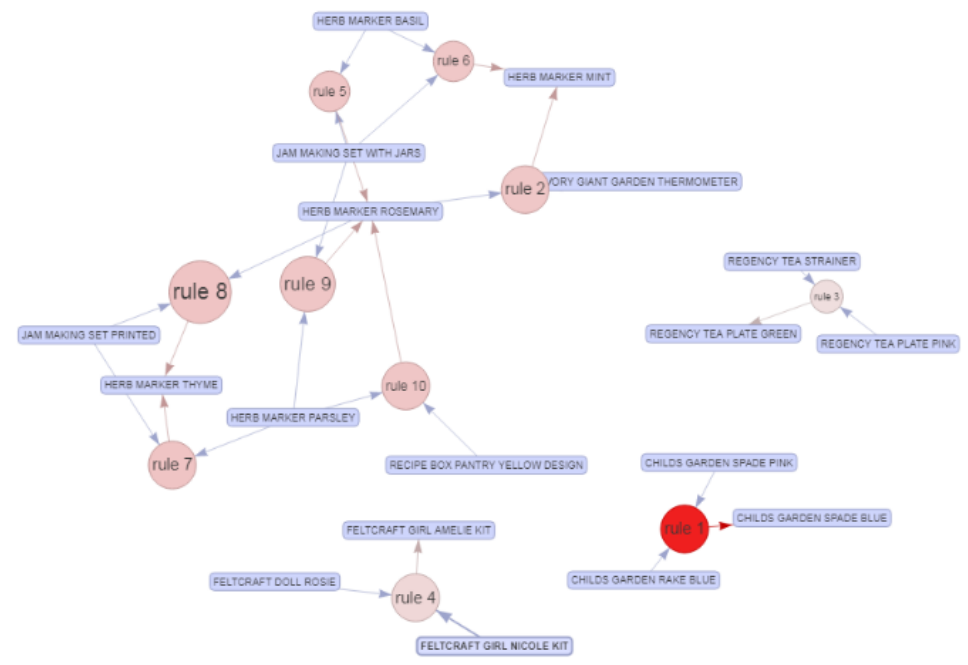

Gambar 11. Hasil Pola Rule yang Terbentuk Dengan Nilai Confidence 60\%

Gambar 11 merupakan hasil pola rule yang terbentuk dengan confidence 60\%. Rule pertama menyebutkan bahwa if ada permintaan untuk membeli produk Child Garden Spade Pink dan Child Garden Rake Blue then akan ada permintaan untuk membeli Child Garden Spade Blue. Hasil pola rule yang terbentuk dengan confidence $70 \%$, pada rule pertama menyebutkan bahwa if ada permintaan untuk membeli produk Child Garden Spade Pink dan Child Garden Rake Blue then akan ada permintaan membeli Child Spade Blue seperti ditunjukkan gambar 12. Sedangkan hasil pola rule yang terbentuk dengan confidence $80 \%$, pada rule pertama menyebutkan bahwa if ada permintaan membeli produk Child Garden Spade Pink dan Child Garden Rake Blue then akan ada permintaan untuk membeli Child Spade Blue seperti ditunjukkan gambar 13.

Didi, et,al (Penerapan Association Rule Mining Berbasis Algoritma Frequent Pattern Growth Untuk Rekomendasi Penjualan) 

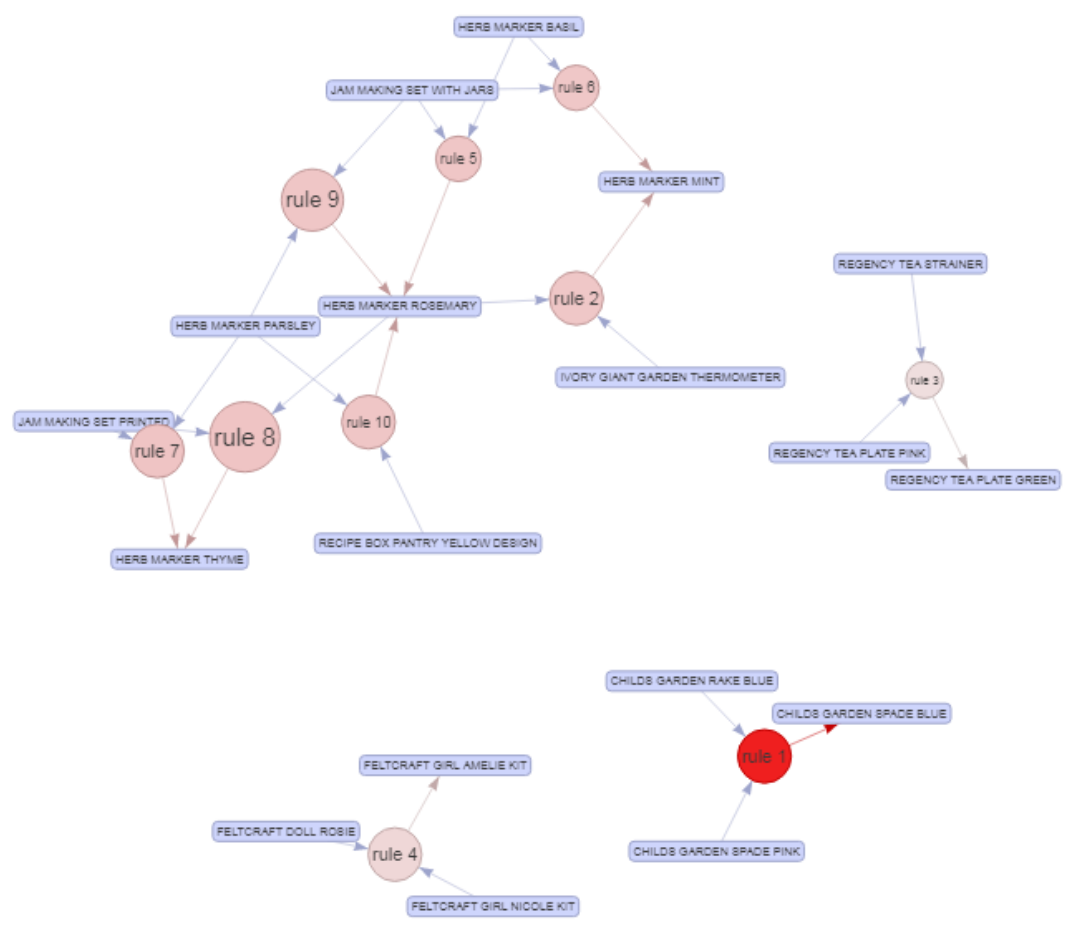

Gambar 12. Hasil Pola Rule yang Terbentuk Dengan Nilai Confidence 70\%

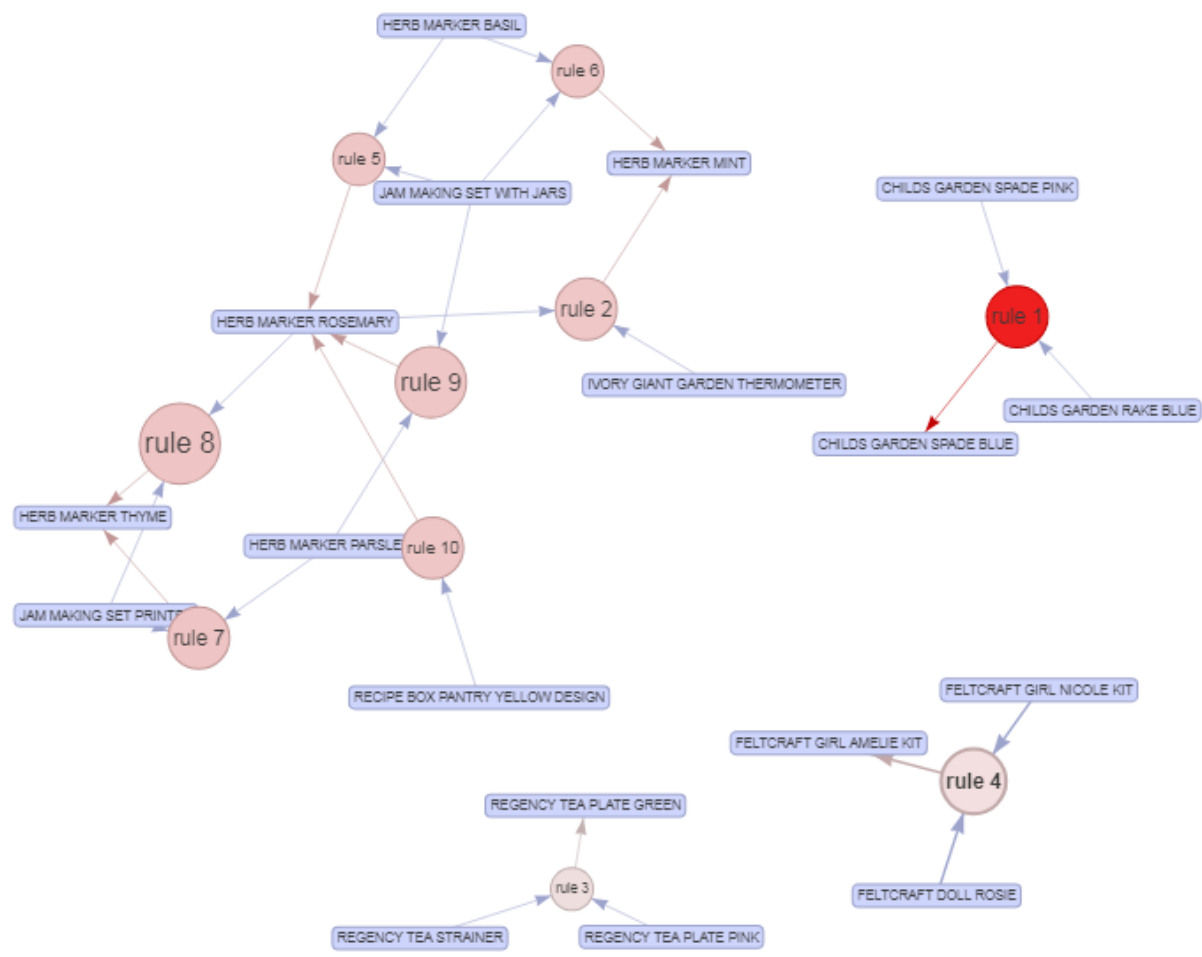

Gambar 13. Hasil Pola Rule yang Terbentuk Dengan Nilai Confidence 80\% 


\section{KESIMPULAN}

Dari penelitian yang dilakukan, diperoleh FP-Growth dengan nilai minimum support $0,1 \%$ dan nilai minimum confidence $60 \%$ jumlah rule yang dihasilkan berjumlah 116457 , nilai minimum confidence $70 \%$ jumlah rule yang dihasilkan berjumlah 84086 , dan nilai minimum confidence $80 \%$ jumlah rule yang dihasilkan berjumlah 48623 . Data yang diolah sebanyak 22191. Hasil rule ini digunakan untuk strategi pemasaran produk. Kesimpulannya dimana semakin besar nilai minimum confidence yang dimasukkan maka menghasilkan rule yang semakin sedikit.

Penelitian Association rule mining menggunakan algoritma FP-Growth kali ini diketahui Jumlah item yang paling banyak terjual diurutkan berdasarkan sepuluh item tertinggi dimana item White Hanging Heart T-Light Holder terjual 1803, item Regency Cakesand 3 Tier terjual 1709, item Jumbo Bag Red Retrospot terjual dengan jumlah 1460, item Party Bunting terjual dengan jumlah 1285 dan item Assorted Colour Bird Retrospot terjual 1250.

\section{SARAN}

Penelitian yang bertujuan untuk memberikan rekomendasi penjualan ataupun strategi pemasaran suatu produk menggunakan Association Rule Mining FP-Growth ini dapat dikembangkan lebih lanjut dengan menerapkan metode tertentu dalam pembentukan $F P$-Tree.

\section{UCAPAN TERIMA KASIH}

Penulis mengucapkan terima kasih kepada kepala LPPM Institut XYZ yang telah memberikan izin dan dukungan terhadap penelitian ini.

\section{DAFTAR PUSTAKA}

[1] D. J. Berndt, M. C. Tremblay, and S. L. Luther, 2009. Data Mining A Knowledge Discovery Approach. New York, USA: Springer.com.

[2] D. Sartika and D. Indra, 2017. "Perbandingan Algoritma Klasifikasi Naive Bayes, Nearest Neighbour, dan Decision Tree pada Studi Kasus Pengambilan Keputusan Pemilihan Pola Pakaian," J. Tek. Inform. Dan Sist. Inf., Vol. 1, No. 2, pp. 151-161.

[3] S. Santosa, 2016. "Analisis Keranjang Pasar untuk Rekomendasi Produk (Consumer Good) Menggunakan Fp-Growth," Tek. Inform., Vol. 12, pp. 103-115.

[4] W. A. Triyanto, 2014. "Association Rule Mining untuk Penentuan Rekomendasi Promosi Produk,” J. SIMETRIS, Vol.5, No.2, pp. 121-126.

[5] K. and M. . D. Dharmaraajan, 2016. "Analysis of FP-Growth and Apriori Algorithms on Pattern Discovery from Weblog Data," IEEE Int. Conf. Adv. Comput. Appl., pp. 170174, 2016, doi: 10.1109/ICACA. 
[6] D. P. Larasati, M. Nasrun, and U. A. Ahmad, 2015. "Analisis dan Implementasi Algoritma Fp-Growth pada Aplikasi Smart untuk Menentukan Market Basket Analysis pada Usaha Retail ( Studi Kasus : Pt . X) Analysis and Implementation of Fp-Growth Algorithm in Smart Application to Determine Market Basket Analysis," Sist. Komput., Vol. 2, No. 1, pp. 749-755.

[7] M. S. Chen, J. Han, and P. S. Yu, 1996, "Data mining: An overview from A Database Perspective," IEEE Trans. Knowl. Data Eng., Vol. 8, No. 6, pp. 866-883, doi: $10.1109 / 69.553155$.

[8] M. Goel and K. Goel, 2017, "FP-Growth Implementation Using Tries for Association Rule Mining," in Proceedings of Sixth International Conference on Soft Computing for Problem Solving, Advances in Intelligent Systems and Computing, pp. 21-29, doi: 10.1007/978-981-10-3325-4.

[9] R. Yanto and H. Di Kesuma, 2017, "Pemanfaatan Data Mining Untuk Penempatan Buku Di Perpustakaan Menggunakan Metode Association Rule," JATISI (Jurnal Tek. Inform. dan Sist. Informasi), Vol. 4, No. 1, pp. 1-10, doi: 10.35957

[10] J. Han and J. Pei, 2000. "Mining Frequent Patterns by Pattern Growth: Methodology and Implications," ACM SIGKDD Explor Newsl., pp. 14-20.

[11] Triyanto. Wiwit Agus, Suhartono. Vincent and and Himawan. H, 2014. "Analisis Keranjang Pasar Menggunakan K Medoids dan FP Growth.pdf," J. Pseudocode, Vol. 2 Nomor 1, September, pp. 129-142. 